\title{
Sinergitas Kementerian dan Lembaga dalam Mengantisipasi Konflik di Laut China Selatan
}

\author{
Renny Setiowati ${ }^{1 *}$, Sundring Pantja Jati ${ }^{1}$, Puji Widodo ${ }^{1}$, Bambang Suharjo ${ }^{1}$ \\ ${ }^{1}$ Universitas Pertahanan \\ Kawasan IPSC Sentul Sukahati Citeureup Kabupaten Bogor 16810 Jawa Barat \\ *rennysetiowatibaru@gmail.com \\ DOI: https://doi.org/10.21107/rekayasa.v14i3.12577
}

\begin{abstract}
The South China Sea is one of the epicenters of conflict in the 21st century. The South China Sea area includes waters and land located in the archipelago of two large islands, namely the Spratlys and Paracels, as well as the banks of the Macclesfield and Scarborough Reef Rivers which stretch from Singapore, from the Malacca Strait to the Taiwan Strait. As this vast territory has often been subjected to successive control by neighboring rulers, several countries, such as the People's Republic of China (PRC), Taiwan, Vietnam, the Philippines, and Brunei Darussalam, have engaged in confrontational attempts to claim, over large parts of the entire territory. . While on the one hand Indonesia supports the prospect of peace in the South China Sea for economic development and domestic stability, Indonesian policymakers are concerned about China's interpretation of its South China Sea claims, which also includes reserves of natural gas and other natural resources. inside it. On the other hand, Indonesia is committed to defending the rights of the archipelagic state as stated in UNCLOS.
\end{abstract}

Key words : south china sea, territory, maritime, conflict

\section{PENDAHULUAN}

Laut China Selatan menjadi episentrum atau pusat dari sengketa maritim yang melibatkan banyak negara di abad 21. Kawasan Laut China Selatan mencakup perairan dan daratan yang berada di dalam gugusan kepulauan dua pulau besar, yakni Spratly dan Paracels, serta bantaran Sungai Macclesfield dan Karang Scarborough yang terbentang luas dari negara Singapura yang dimulai dari Selat Malaka sampai ke Selat Taiwan. Mengingat wilayah yang luas ini sering mengalami penguasaan silih berganti oleh penguasa tradisional negara-negara terdekat, dewasa ini, beberapa negara, seperti Republik Rakyat China (RRC), Taiwan, Vietnam, Filipina, dan Brunei Darussalam, terlibat dalam upaya konfrontatif saling klaim, atas sebagian ataupun seluruh wilayah perairan tersebut. Indonesia, yang bukan negara pengklaim, menjadi terlibat setelah klaim mutlak RRC atas perairan Laut China Selatan

\section{Article History:}

Received: August, 30 th 2021; Accepted: October, 27 2021

Rekayasa ISSN: 2502-5325 has been Accredited by Ristekdikti (Arjuna) Decree: No. 23/E/KPT/2019 August 8th, 2019 effective until 2023 muncul pada tahun 2012

Saat ini, China dan Amerika Serikat menjadi dua dari negara berdaulat yang menjadi kelompok kepentingan dalam saling gugat dalam klaim terkait Laut China Selatan. Amerika Serikat menganggap tindakan China untuk menempatkan alutsista dengan kemampuan dan kapasitas seperti anti-access/area-denial (A2/AD), yang mana akan digunakan untuk tujuan mengendalikan aktivitas perikanan dan pengeboran minyak di area perairan Laut China Selatan, memaksa dan mengintimidasi negara lain yang turut bersengketa soal Laut China Selatan dengan China, menegakkan zona identifikasi udara atau Air Defence Identification Zone (ADIZ) di sekitar Laut China Selatan, memfasilitasi presensi dan proyeksi militer China hingga Pasifik Barat, dan mewujudkan ambisi menjadi hegemon bagi wilayah Eurasia. Bagi Amerika Serikat, dominasi China di Laut China

\section{Cite this as:}

Setiowati, R., Jati, S.P., Widodo, P \& Suharjo, B. (2021). Sinergitas Kementerian dan Lembaga dalam Mengantisipasi Konflik di Laut Cina Selatan. Rekayasa 14 (3). 328-333

doi: https://doi.org/10.21107/rekayasa.v14i3.12577.

(C) 2021 Renny Setiowati 
Selatan berarti gangguan bagi perekonomian Amerika Serikat. Laut China Selatan memiliki rute perdagangan komersial yang dilewati kargo senilai 3,4 triliun dolar per tahun. Kementerian Pertahanan Amerika Serikat menegaskan Laut China Selatan menjadi bagian penting bagi kebijakan luar negeri Amerika Serikat karena 80 persen minyak yang dibutuhkan oleh Jepang, Korea Selatan dan Taiwan melewati jalur tersebut.

Sementara itu, klaim Beijing terhadap Laut China Selatan merujuk pada perjanjian damai Sekutu dengan Jepang pada tahun 1951. Pada perjanjian itu, Perdana Menteri China pada saat itu Zhou Enlain menegaskan klaim kedaulatan terhadap Kepulauan Spratly dan Parasel. Karena perubahan hukum internasional terus terjadi, termasuk penggunaan zona ekonomi eksklusif yang diatur dalam United Nations Convention on the Law of the Sea (UNCLOS), maka klaim China terhadap kepulauan dan laut sekitarnya harus semakin dipertegas dengan kodifikasi hukumhukum yang diperlukan. Pada tahun 1992, Kongres Rakyat Nasional (NPC) mengesahkan UndangUndang tentang Laut Teritorial dan Zona Tambahan Republik Rakyat China, yang menegaskan kembali isi deklarasi 1951 tetapi mengandung bahasa yang lebih spesifik. Mengikuti undang-undang ini, China mengeluarkan baseline atau garis dasar penetapan untuk perairan teritorialnya pada tahun 1996. Pada tahun 1998, NPC melewati undang-undang tentang Zona Ekonomi Eksklusif dan Landas Kontinen Republik Rakyat Tiongkok, di mana ia mengklaim tambahan hak maritim melampaui wewenang yang terkandung dalam undangundang tahun 1992. Zona ekonomi eksklusif dengan interpretasi dari Kongres Rakyat Nasional tidak hanya mengacu pada Paracels atau Spratlys, tetapi, ketika digabungkan dengan undangundang tahun 1992 tentang laut teritorial memberikan dasar untuk mengklaim hak maritim di Laut Cina Selatan.

\section{Posisi Indonesia dalam Sengketa Laut China Selatan}

Persoalan Laut China Selatan ini tidak terpisahkan dengan ASEAN, karena mayoritas negara yang berkonflik hampir sebagian besar adalah negara-negara anggota ASEAN seperti Filipina, Vietnam, Malaysia dan Brunei Darusallam. Negara anggota ASEAN ini memperjuangkan kepentingan yang mereka miliki di Laut China Selatan, yakni wilayah yang mereka yakini sebagai kedaulatan mereka beserta kekayaan alam didalamnya, serta berbatasan langsung dengan Laut China Selatan. Menjelang keluarnya putusan Arbitral Tribunal, RRC telah melakukan kampanye yang sistematis dan masif untuk menggalang dukungan atas posisinya yang menolak Arbitral Tribunal. Republik Rakyat China (RRC) secara terang-terangan mendesak agar ASEAN tidak mengeluarkan pernyataan atas putusan Arbitral Tribunal.

Arbitral Tribunal yang dimaksud adalah gugatan Filipina ke Republik Rakyat China ke Arbitral Tribunal UNCLOS 1982 pada tanggal 22 Januari 2013. Materi gugatan Filipina ke Tribunal ini tidak berkaitan dengan kepemilikan fitur maritim atau delimitasi maritim mengingat Tribunal tidak berwenang untuk mengadili ke dua isu ini, tetapi permasalahan keabsahan nine dash line RRC dan soal apakah lokasi atau landmark maritim yang disengketakan adalah pulau yang berhak melahirkan zona ekonomi eksklusif atau hanya berstatus elevasi surut yang tidak berhak atas zona apapun. Dalam amar putusan setebal 497 halaman, mahkamah menyatakan klaim Cina tersebut tidak memiliki dasar hukum dan menolak hak sejarah dari China di LCS. Keputusan itu juga menjelaskan bahwa pulau buatan Cina di atas terumbu karang di kawasan itu tidak dapat dianggap sebagai Zona Ekonomi Eksklusif (ZEE) 200 mil dan wilayah perairan 12 mil.

Indonesia bersama dengan negara-negara lain telah memprotes dan tidak mengakui eksistensi nine dash line dalam peta RRC karena penarikan garis ini tidak mengikuti kaidah hukum internasional dan hukum laut internasional yang berlaku. Dalam konteks ini Indonesia melihat garis ini sebagai persoalan semua negara khususnya para pihak pada UNCLOS dan bukan semata-mata persoalan bilateral Indonesia- RRC.

Pada perairan Natuna, Indonesia telah membuat garis perbatasan landas kontinen dengan Malaysia pada tahun 1969 dan telah didaftarkan ke PBB. Indonesia juga telah mengeluarkan Deklarasi ZEE pada tanggal 21 Maret 1980 (dan mendaftarkannya ke PBB) yang menggambarkan zona maritim selebar 200 mil laut dari garis pangkal di Natuna. Kedua instrumen ini tidak pernah diprotes oleh RRC. Indonesia tidak sepakat dengan penggunaan atol-atol dan karang 
di Laut China Selatan oleh RRC sebagai dasar penyusunan nine dash line, namun beranggapan titik terdekat yang dimiliki Indonesia di Natuna yakni Cuaerteron Reef tidak berdempetan dengan wilayah klaim baik yang diperdebatkan antara Malaysia, Vietnam, dan China.

\section{Kepentingan Indonesia di Laut China Selatan}

Dari aspek pertahanan, gugatan berbagai claimant state menjadi tantangan bagi Indonesia untuk mempertahankan klaimnya di Laut Natuna Utara, sebagaimana merujuk di dalam United Nations Conventions on The Law of the Sea (UNCLOS) tahun 1982. Dengan dasar hukum tersebut yang kemudian diratifikasi, Indonesia memiliki hak berdaulat untuk mengeksplorasi sumber data alam yang ada di dalamnya. Menurut aspek ekonomi, potensi ekonomi berupa perikanan dan gas alam sangatlah besar. Berdasarkan keterangan yang diberikan oleh Kementerian Energi dan Sumber Daya Mineral (ESDM), Blok East Natuna memiliki kandungan potensi minyak dalam kisaran 36 jta barel minyak dan gas alam di tempat (Intial Gas in Place/IGIP) sebanyak 22 triliun kaki kubik.

Stabilitas kawasan adalah kunci dari menguatnya Laut China Selatan sebagai pusat aktivitas perdagangan karena kawasan LCS mengandung nilai ekonomis, politis, dan strategis sebagai Sea Lanes of Trade (SLOT) dan Sea Lanes of Communication (SLOC) yang menghubungkan Samudera Hindia dan Samudera Pasifik. Jika dibahas secara lebih mendalam, SLOC merupakan rute maritim antar pelabuhan-pelabuhan yang digunakan untuk kegiatan pelayaran internasional yang meliputi perdagangan, pengiriman logistik, dan angkatan laut. Sebagai jalur pelayaran internasional, kawasan LCS merupakan rute utama bagi sepertiga perdagangan maritim dunia. Selain itu, jalur ini juga mengarahkan volume lalu lintas transportasi pengiriman perdagangan maritim seperti minyak mentah dengan volume pelayaran mencapai 1.000 unit kapal per hari.

\section{Strategi Untuk Mengantisipasi Konflik di Laut China Selatan}

Diplomasi pertahanan menjadi salah satu pendekatan pertama yang Pemerintah Indonesia gunakan untuk menghadapi berbagai klaim yang saling berselisih di LCS, terutama klaim yang berkaitan dengan kepulauan Natuna. Gagasan untuk lebih mendorong narasi diplomasi pertahanan mulai dilancarkan pada awal tahun 2015, atau bertepatan dengan meningkatnya narasi Beijing dalam menghadapi klaim dari negara-negara yang berselisih menggunakan teksteks sejarah yang diotorisasi Pemerintah China untuk memperkuat legitimasi atas wilayah tersebut. Selain itu, Indonesia juga mengumumkan rencana untuk membangun lebih banyak pos militer di wilayah perbatasan untuk menjaga kedaulatan dan keutuhan wilayah nusantara terutama di wilayah yang berhadapan dengan LCS. Diikuti dengan berbagai upaya posturing berupa ketegasan dan penempatan kekuatan militer di wilayah yang menjadi bagian dari klaim negaranegara yang bersengkata, hasil-hasil yang bisa diharapkan adalah sebagai berikut:

1. Meminta klarifikasi nine dash line dengan 2 metode yaitu klarifikasi oleh Tiongkok dan klarifikasi oleh Tribunal.

2. Menggunakan KTT sebagai forum diskusi antara ASEAN dan Tiongkok, hal ini memperhatikan kepentingan ASEAN yang menginginkan penyelesaian dengan forum multilateral.

3. Menggunakan dialog bilateral, hal ini memperhatikan keinginan China atas meluruskan ketidak sepakatan atas klaim di LCS.

4. Belajar dari kelemahan Declaration on the Conduct of Parties in the South Cina Sea (DOC) yang tidak mengikat para pihak mengingat deklarasi tersebut hanyalah dokumen politik yang tidak memiliki kekuatan hukum mengikat, serta tidak memiliki sanksi yang mengikat dan bisa diterapkan.

5. Mendorong implementasi code of conduct yang akan digunakan oleh negara-negara yang memiliki klaim sebagai panduan untuk mengatur lintas batas beserta eksploitasi sumber daya alam di wilayah sengketa.

\section{Strategi Pertahanan Indonesia di Laut China Selatan}

Indonesia berkomitmen untuk mewujudkan diplomasi pertahanan dengan aspek-aspek yang terdiri dari menciptakan enabling environment yang memungkinkan negara-negara yang tergabung sebagai claimant state untuk bertemu dan menegosiasikan perbedaaan mereka terkait wilayah klaim yang berdempetan, mendorong peningkatan kerjasama ekonomi di kawasan, mempertahankan 
kebijakan politik luar negeri yang bebas aktif, serta penegakan hukum di Zona Ekonomi Eksklusif (ZEE) Indonesia. Untuk aspek pertama, Indonesia adalah inisiator dari Declaration on the Conduct of Parties in the South China Sea (DOC) yang berjalan sampai saat ini. Dalam rentang waktu 2017-2019, Indonesia berhasil mempertemukan ASEAN dan RRC untuk menyelesaikan rancangan tunggal teks negosiasi kode etik Laut China Selatan yang bertajuk Single Draft China Sea Code of Conduct Negotationg Text yang mencakup 5 fokus. Fokus-fokus tersebut adalah ruang lingkup geografis Laut China Selatan, upaya penyelesaian sengketa, kewajiban untuk berkooperasi dalam pelestarian lingkungan maritim, peran pihak ketiga di Laut China Selatan, dan legal status code of conduct.

Secara ekonomi, meningkatkan aktivitas ekonomi di wilayah perbatasan bisa meningkatkan legitimasi pemerintah terkait klaim kedaulatan di Natuna. Pemerintah telah menetapkan Natuna sebagai sentra ekonomi perikanan melalui Sentra Kelautan dan Perikanan Terpadu (SKPT) merujuk KM KP No. 51/KEPMEN-KP/2016 tentang Penetepan Lokasi Pembangunan Sentra Kelautan dan Perikanan Terpadu di Pulau- Pulau Kecil dan Kawasan Perbatasan. SKPT sebagai kebijakan perekonomian sudah terbukti efektif di lokasi lain yang sudah melaksanakan kebijakan ini sebelumnya, seperti Sebatik. pembangunan SKPT Sebatik menjadikan Sebatik sebagai pusat perekonomian baru di wilayah perbatasan Indonesia akan memindahkan sebagian kegiatan perekonomian (dalam hal ini perdagangan komoditas hasil perikanan) tidak hanya berlangsung pada Tawau (Malaysia) sebagai pasar utama, tapi juga mendorong penguatan pasar baru dengan memunculkan peluang mengundang konsumen untuk langsung membeli produk perikanan di Sebatik. Penjajakan peluang kerjasama yang sudah terjadi di SKPT Sebatik terdiri dari usaha budidaya udang dan kepiting bakau, selain terkait dengan peluang pasar dari udang dan kepiting bakau, juga peluang untuk mengatasi permasalahan kekurangan benur udang dan belum ada usaha pembenihan kepiting bakau.

Tentunya, diplomasi pertahanan akan sulit berjalan tanpa militer yang mumpuni dan tangguh. TNI Angkatan Laut perlu menjalankan apa yang dinamakan dengan pertahanan berlapis, yang terdiri dari pertahanan sebelum musuh mampu memasuki ZEE Indonesia dan pertahanan setelah musuh sudah memasuki ZEE Indonesia. Untuk lapisan pertama, diperlukan infrastruktur maritim yang mampu menjalankan tugas untuk meningkatkan perkembangan ekonomi, distribusi logistik yang merata, kemudahan transportasi, dan mobilisasi pertahanan negara. Pangkalan militer adalah tempat pertahanan utama dan titik fokus mobilisasi di wilayah tersebut. Selain itu, pangkalan militer juga mendorong pihak militer untuk melakukan pemantauan wilayah di sekitarnya dengan lebih intens, karena bisa melakukan pemeliharaan dengan lebih sering dan mengurangi potensi atrisi karena alutsista yang ada kurang terawat. Kemudian, pelabuhan-pelabuhan umum akan membuat kebutuhan yang biasa ditemukan dalam operasi militer seperti ransum dan bahan bakar minyak menjadi lebih terjangkau dan mudah ditemukan. Dengan operasi logistik yang efisien, militer dapat meringankan beban persediaan dan peralatan untuk memangkas waste, seperti transportasi logistik, pergerakan yakni pengangkutan dan pemindahan barang dan pada saat bersamaan peningkatan ketahanan atau sustainability pasukan di medan perang.

Latihan dan operasi yang dilakukan secara rutin pada akhirnya harus menghasilkan apa yang dinamakan dengan picture building. Picture building adalah membangun impresi TNI sebagai pihak yang kompeten dan tegas baik dalam Operasi Militer Perang (OMP) maupun Operasi Militer Selain Perang (OMSP). TNI secara berkelanjutan dan berkesinambungan harus mampu menunjukkan kesan yang lembut dan mampu menjadi penengah di dalam konflik yang sedang terjadi sekaligus menampilkan kesan sebagai pelindung kedaulatan beserta orang-orang yang ada di dalamnya. Dalam tugasnya menurut Undang-Undang No. 34 tahun 2004, TNI memiliki tugas pokok yang dibagi menjadi 2 jenis, yakni Operasi Militer untuk Perang atau OMP dan Operasi Militer Selain Perang atau OMSP. Dalam OMSP, tugas-tugas TNIAL tidak terkhusus pada perang, penyerangan, dan penggunaan senjata, namun memiliki jangkauan yang jauh lebih luas dalam banyak aspek seperti sosial, politik dan kemanusiaan. Melalui beragam misi kemanusiaan, serta dengan didukung oleh alutsista yang handal, maka usaha picture-building dapat memberikan kesan bahwa TNI-AL mampu menggunakan kekuatan mereka dalam hal yang humanis dan mendukung perdamaian. 
Setelah melakukan diplomasi pertahanan dan mobilisasi yang bersifat pencegahan atau deterrence, penegakan hukum perlu dilakukan sehingga pelanggar batas kedaulatan di Laut China Selatan bisa mengamati jika hukum Indonesia berlaku di wilayah kedaulatan. Badan Keamanan Laut (BAKAMLA) memiliki banyak sarana untuk melakukan penegakan hukum di laut lepas. Secara garis besar, Vesse Monitoring System (VMS) dan Automatic Identification System (AIS) menjadi sumber daya operasional Bakamla dalam berpatroli.

Sistem Pemantauan Kapal Perikanan/ Vessel Monitoring System (VMS) merupakan bentuk sistem pengawasan di bidang penangkapan dan/atau pengangkutan ikan dengan memanfaatkan satelit dan peralatan transmitter yang dioperasikan pada kapal perikanan guna mempermudah pengawasan dan pemantauan terhadap kegiatan/aktifitas kapal ikan berdasakan posisi kapal yang terpantau di monitor Vessel Monitoring System Pusat Pemantauan Kapal Perikanan (Fisheries Monitoring Center) di Jakarta atau di daerah Unit Pelaksana Teknis (UPT) Pengawasan. Vessel Monitoring System (VMS) adalah sistem penjejakan (tracking system) yang hanya memberikan informasi kepada kapal yang membawa transmitter. Jadi kapal yang tidak memiliki dan kapal lain yang tidak di lengkapi transmitter yang syarat-syaratnya sudah ditetapkan tidak akan terpantau oleh VMS.

Automatic Identification System atau AIS adalah sebuah sistem yang digunakan kapal untuk berbagi informasi antara dua kapal atau lebih. Informasi yang dibagikan diantaranya: (1). Identitas kapal seperti: mana kapal, nomor IMO, nomor MMSI, dan call sign, (2). Posisi, kecepatan dan arah gerakan kapal, dan (3). Pelabuhan tujuan kapal. Dalam sistem AIS, pertukaran data berlangsung otomatis dengan memanfaatkan perangkat AIS yang dipasang di kapal, dengan gelombang radio sebagai medium. Dalam rangka penegakan hukum di wilayah perairan dan wilayah yurisdiksi, khususnya dalam melaksanakan patroli keamanan dan keselamatan di wilayah perairan dan wilayah yurisdiksi Indonesia, dibentuk Badan Keamanan Laut. Berdasarkan Undang-Undang Nomor 32 Tahun 2014 tersebut TNI AL sebagai penegak hukum sekaligus penyidik sedangkan Bakamla hanya melaksanakan patroli keamanan dan keselamatan penegakkan hukum tidak melakukan penyidikan (bukan sebagai penyidik).

\section{KESIMPULAN}

Sinergitas merupakan kombinasi atau paduan unsur/bagian yang dapat menghasilkan keluaran lebih baik dan lebih besar ketika dibangun secara baik bersama stakeholder yang ada didalamnya dengan tujuan untuk membangun masyarakat atas kerjasama yang saling menguntungkan dan dilandasi pemikiran-pemikiran yang rasional, terbuka dan demokratis. Politik Luar Negeri Indonesia di LCS adalah mencoba untuk menggerakan enabling environment to engage in dialogue, mendorong peningkatan kerja sama ekonomi di kawasan, RI harus mempertahankan kebijakan polugri bebas aktif dan penegakan hukum di ZEEI untuk melindungi hak berdaulat Indonesia. Setelah adanya Putusan Arbitrase LCS maka pernyataan Indonesia adalah:

a. Mendorong semua pihak untuk menahan diri dari meningkatkan ketegangan, menjaga Asia Tenggara dari aktivitas militer yang dapat mengancam stabilitas dan perdamaian, serta menghormati hukum Internasional termasuk UNCLOS.

b. Meminta semua Pihak untuk meneruskan komitmen bersama menjaga perdamaian serta menunjukkan rasa persahabatan dan kerja sama.

c. Indonesia akan terus mendorong pembentukan kawasan Asia Tenggara sebagai zona damai, kebebasan, dan netral untuk memperkuat Komunitas Politik dan Keamanan ASEAN.

d. Mendorong seluruh Claimant States untuk meneruskan perundingan damai atas klaim tumpang tindih mengenai kedaulatan di LCS sesuai dengan hukum internasional.

\section{DAFTAR PUSTAKA}

Bayu Vita Indah Yanti. 2018. Dinamika Kesepakatan Perdagangan Lintas Batas Antara Indonesia dan Malaysia dan Pengembangan Sentra Kelautan dan Perikanan Terpadu Sebatik, Kebijakan Sosek KP Vol. 10

Booth, K., 2014. Law, force and diplomacy at sea, 1st ed. New York: Routledge

Evan A Laksmana. 2019. Drifting Towards Equilibrium: Indonesia South China Sea Policy Under Yudhoyono, Yusuf Ishak Institute

Gerald Theodorus. 2019. Peran Strategis Indonesia dalam Penyelesaian Konflik Laut China Selatan 
dalam perspektif Stabilitas Keamanan Regional, Jurnal Keamanan Nasional

Kebijakan Pertahanan Negara Tahun 2021, Kementerian Pertahanan

Patrik Kristophe MeyeR. 2024. Indonesia Swift Securitization of The Natuna Islands, Asian Journal of Political Science
Taylor Fraven, China's Strategy in the South China Sea, Massachussets Institute of Technology, January 2015

Yuli Ari Sulistyani, Andhini Citra Pertiwi, Indonesia's Responses toward the South China Sea Dispute During Joko Widodo's Admininstration, Jurnal Politica 